
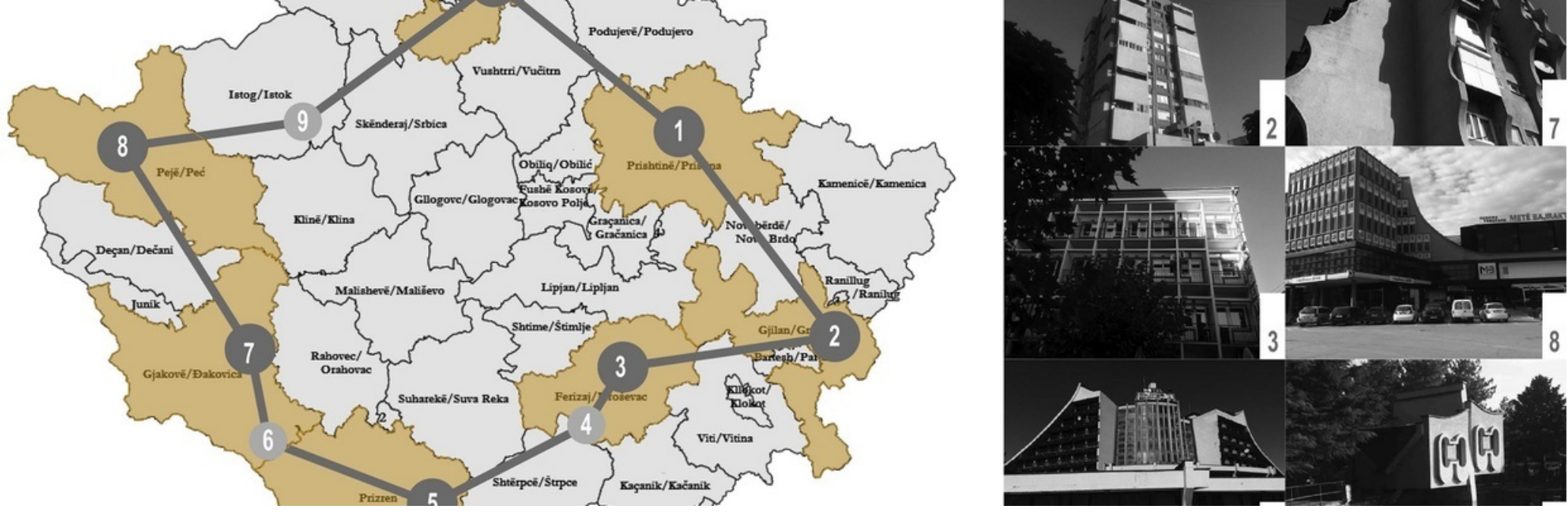

\title{
The Journey of Kosovo Modernism: A Process of Metamorphosis
}

Authors: $\quad$ Flaka Xërxa Beqiri, Vlora Navakazi, Bardha Meka

Submitted: 15. April 2021

Published:

15. April 2021

Volume:

8

Issue: 2

Affiliation:

Languages:

University of Prishtina, Kosovo

Keywords:

English

architecture, modernism, Kosovo, socialist modernism, modernist heritage

Categories: $\quad$ Visual Arts, Architecture and Design

DOI: $\quad$ 10.17160/josha.8.2.749

Abstract:

Kosovo Modernism counts a significant number of good architecture examples, easily compered with the construction activity of the socialist modernism in the region. Yet, compered to the architecture of the same period of other countries of Yugoslavia, it remains a 'grey area'. It is less analysed and documented compared with the Byzantine and Islamic Architecture, whose conquest counts a significant influence on building urban and architectonic identity of the country. Modernism in Kosovo came in the name of prosperity and progress. But this meant that a number of traditional buildings and old city cores were erased following the maxim 'destroy the old, place the new', to make place for new modernist structures. Major cities of Kosovo witnessed major transformations. Also, these transformations were not led by the local authorities, but were mostly imposed from outside. Consequently, for many reasons, modernist architecture has enjoyed a negative reputation in Kosovo as being foreign and imposed. As a result of this negative reputation,as well as other significant factors - such as political and social changes after '99s war in Kosovo. mostlv connected with the process of privatization - the second urban

\section{JOSHA Jumna orsemene. Humanities and Arts}




\title{
The Journey of Kosovo Modernism:
}

\section{A Process of Metamorphosis}

\section{FLAKA XËRXA BEQIRI}

Faculty of Architecture, University of Pristina "Hasan Prishtina", St Ark. Karl Gega, No 1, 10000

Prishtina, Republic of Kosovo, flaka.xerxa@uni-pr.edu

\section{VLORA NAVAKAZI1}

Faculty of Architecture, University of Pristina "Hasan Prishtina", St Ark. Karl Gega, No 1, 10000 Prishtina, Republic of Kosovo, vlora.navakazi@uni-pr.edu

\section{BARDHA MEKA}

Faculty of Architecture, University of Pristina "Hasan Prishtina", St Ark. Karl Gega, No 1, 10000 Prishtina, Republic of Kosovo, bardha.meka@uni-pr.edu

\begin{abstract}
Kosovo Modernism counts a significant number of good architecture examples, easily compered with the construction activity of the socialist modernism in the region. Yet, compered to the architecture of the same period of other countries of Yugoslavia, it remains a 'grey area'. It is less analysed and documented compared with the Byzantine and Islamic Architecture, whose conquest counts a significant influence on building urban and architectonic identity of the country. Modernism in Kosovo came in the name of prosperity and progress. But this meant that a number of traditional buildings and old city cores were erased following the maxim 'destroy the old, place the new', to make place for new modernist structures. Major cities of Kosovo witnessed major transformations. Also, these transformations were not led by the local authorities, but were mostly imposed from outside. Consequently, for many reasons, modernist architecture has enjoyed a negative reputation in Kosovo as being foreign and imposed. As a result of this negative reputation, as well as other significant factors - such as political and social changes after '99s war in Kosovo, mostly connected with the process of privatization - the second urban and architectural destruction in Kosovo started in the beginning of the 21st century. This time not the destruction of the traditional structures, but of the modernist heritage. With the evaluation of certain examples of material production of Kosovo modernism, using the comprehension methodology of the initial and the current state, this paper intends to bring light to the journey of the modernist architecture of Kosovo, its construction and deconstruction phases and the reasons after the neglected appreciation of its values. It aims to show the hidden values of Kosovo modernist architecture and the urge for its valuation, documentation and preservation.
\end{abstract}

Keywords: architecture, modernism, Kosovo, socialist modernism, modernist heritage

\footnotetext{
1 Vlora Navakazi, corresponding author
} 


\section{INTRODUCTION}

\section{THE JOURNEY OF KOSOVO MODERNISM}

After World War Two, Kosovo remained (under Serbian Federation) part of Federal People's Republic of Yugoslavia, which consisted of six republics. ${ }^{2}$ The influence of Yugoslav Architecture, dominated Kosovo. ${ }^{3}$ While Byzantine and Islamic Architecture bought in Kosovo most important public buildings of the time, such as churches, mosques, Turkish baths, open bazars etc., further political movements forced major changes in Kosovo's architecture and cultural identity. After year 1945 we count major changes in built heritage, with the rapid destruction of the old trade markets, city centres and historical monuments The existing built cultural heritage had to be replaced with new structures, under the slogan of the urban development "destroy the old, build the new". 4

\subsection{FIRST DESTRUCTION: ERASING TRADITIONAL STRUCTURES}

A decent number of traditional buildings and old city cores were erased to make place for new modernist structures (Figure 1). The new Kosovo's architecture in major cities of Kosovo was constructed in account of the destruction of the existing heritage and in the name of new architectural identity, questioning the connection with urbanity and national habitat. ${ }^{5}$ Under the fast urbanization, based on the socialist and modernist ideological orientation of the time ${ }^{6}$, major cities of Kosovo had to transform into new cities, following the examples of urban centers of Yugoslavia. The new developments of urban core in most important cities of Kosovo were seen in the new investments in boulevards and mostly in public and residential buildings. ${ }^{7}$

City centers, which had the most concentrated elements of the built heritage, religious, residential, trade and artisan structures, facilities for refreshment and other structures of traditional environmental values, turned into areas with potential of developing new urban structures, minimally influenced in the heritage values of the context, and maximally oriented in the new developments of the neighbouring cities, such as Belgrade, Ljubljana, Zagreb, Skopje etc. To achieve this, new structures followed universal norms and standards ${ }^{8}$, bringing new architectural spirit for Kosovo, but very similar to what was already happening

\footnotetext{
2 Limani, M. (2017): "Kosova in Yugoslavia - Against colonial status", Yugoslavia from a Historical Perspective, ed. by Perovič, L., Roksandič, D., Velikonja, M., Hoepken, W., Bieber, F., Helsinki Committee for Human Rights in Serbia, Belgrade.

${ }^{3}$ Gjinolli, I., Kabashi, L. (2015): Kosovo Modern: An Architectural Primer. National Gallery of Kosovo, Prishtinë.

${ }^{4}$ Hoxha, E. (2013): Qyteti dhe dashuria. Qendra për hulumtime humanistike, Prishtinë.

${ }^{5}$ Fehmiu, B. (1971): Prizren - Remek Delo Nepoznatih Majstora. V: Arhitektura i Urbanizam, 1964-95. Belgrade.

${ }^{6}$ Mrduljoš, M., Kulič, V., McMaster, G. (2012): Unfinished modernisation: between utopia and pragmatism (architecture and urban planning in the former Yugoslavia and the successor states). UHA/CCA, Zagreb.

${ }^{7}$ Gjinolli, I., Kabashi, L. (2015): Kosovo Modern: An Architectural Primer. National Gallery of Kosovo, Prishtinë.

${ }^{8}$ Hoxha, E. (2013): Qyteti dhe dashuria. Qendra për hulumtime humanistike, Prishtinë.
} 
in wider region. A platform for new political and social movement in Kosovo was being promoted.

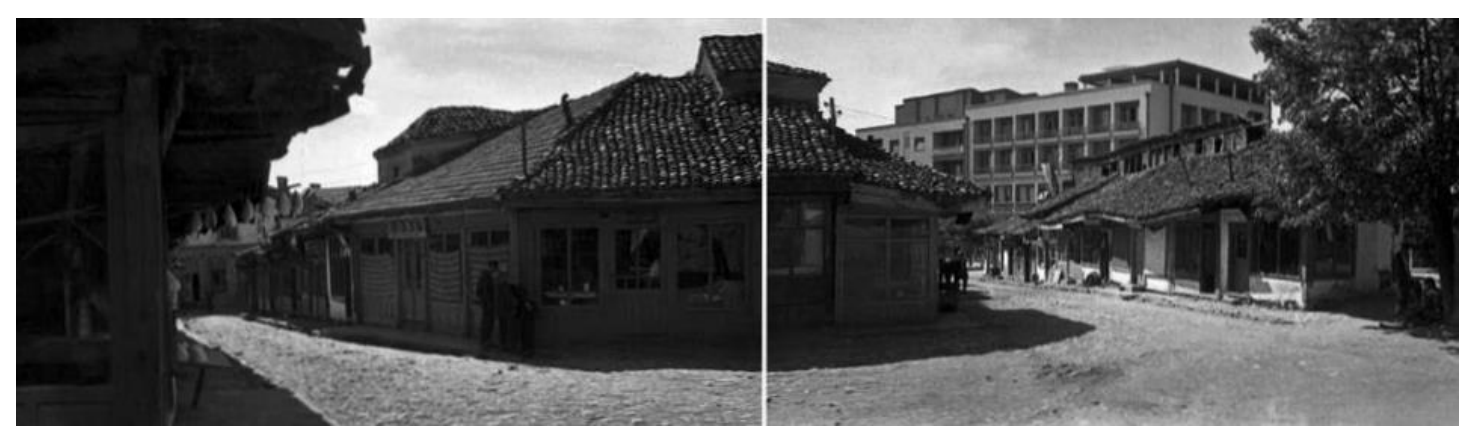

Figure 1: Prishtina, Old Bazar with a background of new modernist structures, 1950 @ Credits: Anonymous Collection of Museum of Kosovo - Prishtina Poetic Memories http://prishtinapoeticmemories.com/indexsh.html

The external forces, in this case political and social context of the time, transformed major cities in Kosovo, migrating their identity from oriental spirit with narrow streets to huge boulevards and 'socialist concrete'. ${ }^{9}$ The architecture of socialist Yugoslavia bought the light of a cultural movement that was already gravitating in most of the countries in Yugoslavia. As valued, Yugoslavia was a country deriving between traditional cultures and competing concepts of modernization. ${ }^{10}$ This diversity lidded to a valuable movement in Kosovo's architecture, the modernist architecture.

\subsection{CONSTRUCTION: BUILDING KOSOVO MODERNISM}

While loosing the connection with its cultural heritage, mostly influenced from Byzantine and Islamic architecture, Kosovo in the same time was opened toward new architectural qualities (Figure 2), featuring rationalism to the dynamic plasticism. ${ }^{11}$

The social, cultural and architectural developments of Kosovo started in 1950s, and continued till late 1980s, aiming to bring 'modern contemporary' cities. However, the decade of the 1970s in Yugoslavia could in many ways be considered the golden age regarding the development of architecture in Kosovo. ${ }^{12}$ This was the time of extensive modernization and urbanization in tune with the socialist ideas, which required also a

\footnotetext{
${ }^{9}$ EU/CoE Support of Promotion of Cultural Diversity - PCDK. (2012): Conservation Bases for the Historic Centre of Pristina. Pristinë

${ }^{10}$ Kulič, V. Mrduljaš, M., Thaler, W., (2012): Modernism In-Between, The Mediatory Architecture of Socialist Yugoslavia. Verlag GmbH, ISBN 978-86859-147-7, Berlin

${ }^{11}$ Mutnjakovič, A. (1981): Dileme kosovske arhitekture. V: Arhitektura - časopis saveza arhitekata hrvatske, 178+9/'81. Zagreb

12 Jashari-Kajtazi, T. (2016): BEHIND THE NATIONAL IDENTITY; Political and Social Activity through Architecture - Liberal Socialism in Kosovo. PhD diss. Wien: TU Wien
} 
significant construction of housing and civic structures. ${ }^{13}$ This period is characterized also by the willingness of the Yugoslavian government to apply advanced urban planning and architectural design in the rapid process of urbanization. In the 1960s and 1970s also the political position of non-Slavic groups within Yugoslavia improved significantly. This was the case also for the region of today's Republic of Kosovo. ${ }^{14}$

The political status of the Autonomous Province of Kosovo and Metohija (1945 - 1963) was in 1963 changed from the 'autonomous region' to the 'autonomous province' and in 1968 to the 'socialist autonomous province'. This was the moment when Kosovo received its own constitution (Kushtetuta e Krahinës Socialiste Autonome të Kosovës, 1974) and began to be represented in federal institutions, retaining a complete state apparatus including a Parliament, Supreme Court and independent police force..$^{15}$ Since Kosovo was granted to have its own administration, assembly and judiciary it also needed the buildings to house these political bodies and institutions. It also became evident that it had to be modernized and urbanized, in short, the need to build modern cities of Kosovo was evident. Modern architecture was seen as a tool that could be used in this process of modernization and urbanization as well as incorporation of the Province of Kosovo into the developed modern Socialist Federal Republic of Yugoslavia.

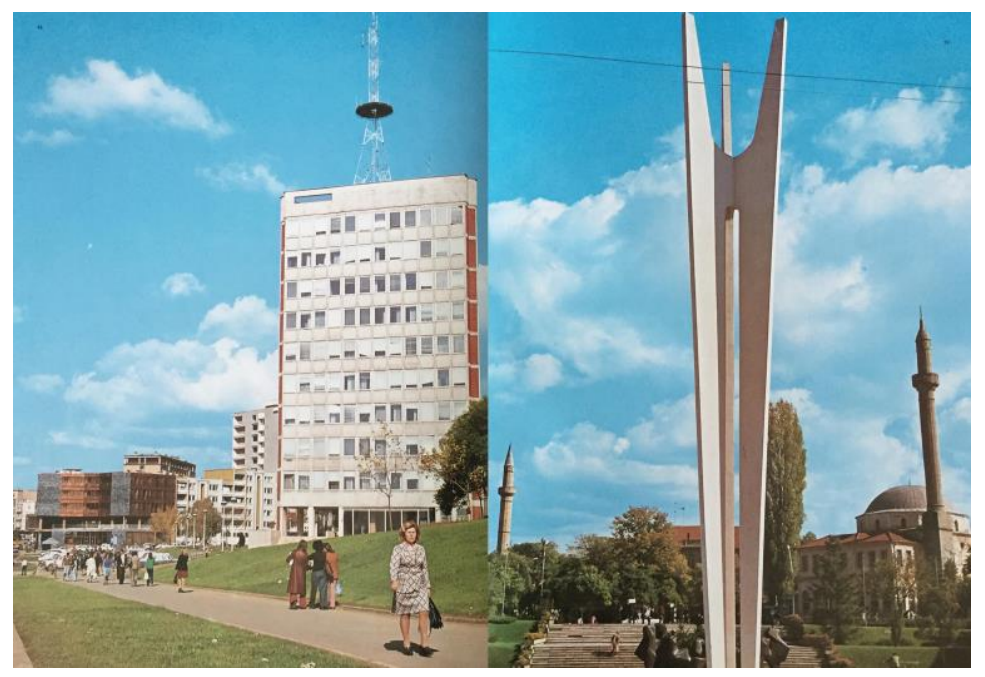

Figure 2: a. Radio Televiosion of Pristina, b. Unity and Brotherhood Square in Pristina @ Credits: Dobroshi, Drita. Socijalistička Autonomna Pokrajina - KOSOVO DANAS. Belgrade: Izdavačka radna organizacija Svetozar Markovič, 1984

During the modernist period, Kosovo became a land of opportunities where architects from other republics of Yugoslavia, and later on also local architects, could express their architectural statements. While cities of Kosovo were going through a process of transition,

\footnotetext{
${ }^{13}$ Mrduljoš, M., Kulič, V., McMaster, G. (2012): Unfinished modernisation: between utopia and pragmatism (architecture and urban planning in the former Yugoslavia and the successor states). UHA/CCA, Zagreb.

14 Ibid.

${ }^{15}$ Limani, M. (2017): "Kosova in Yugoslavia - Against colonial status", Yugoslavia from a Historical Perspective, ed. by Perovič, L., Roksandič, D., Velikonja, M., Hoepken, W., Bieber, F., Helsinki Committee for Human Rights in Serbia, Belgrade.
} 
with the urban regeneration of old city cores and the construction of main public facilities, community of architects took the opportunity to participate as well as to contribute to the state agenda, that of a modernizing Kosovo and incorporating it or placing it on the same level of urban and technological development as the rest of Yugoslavia.

During modernist period, major cities of Kosovo were already planning and bringing designs of most representative buildings, listing here administrative city buildings, libraries, cultural houses, city hotels, post offices, bank offices, sport facilities etc. The need for modernist cities, emerged all national and city capacities in designing modernist city centers, planning new neighbourhoods, designing new industrial areas and generally re-conceptualizing the urban and spatial solutions of main cities of Kosovo. However, the process of modernization and the attainment of the prosperity for Kosovo didn't simply include major cities (Pristina, Mitrovica, Prizren, Peja, Ferizaj, Gjilan, Gjakova). It also included the turning of un-urbanized areas into touristic and new attractive meeting points for the entire region (Brezovica, Landovica and Istog). Kosovo was gradually transformed and modern architecture and urban planning was used as a tool and support of this transformation (Figure 3).
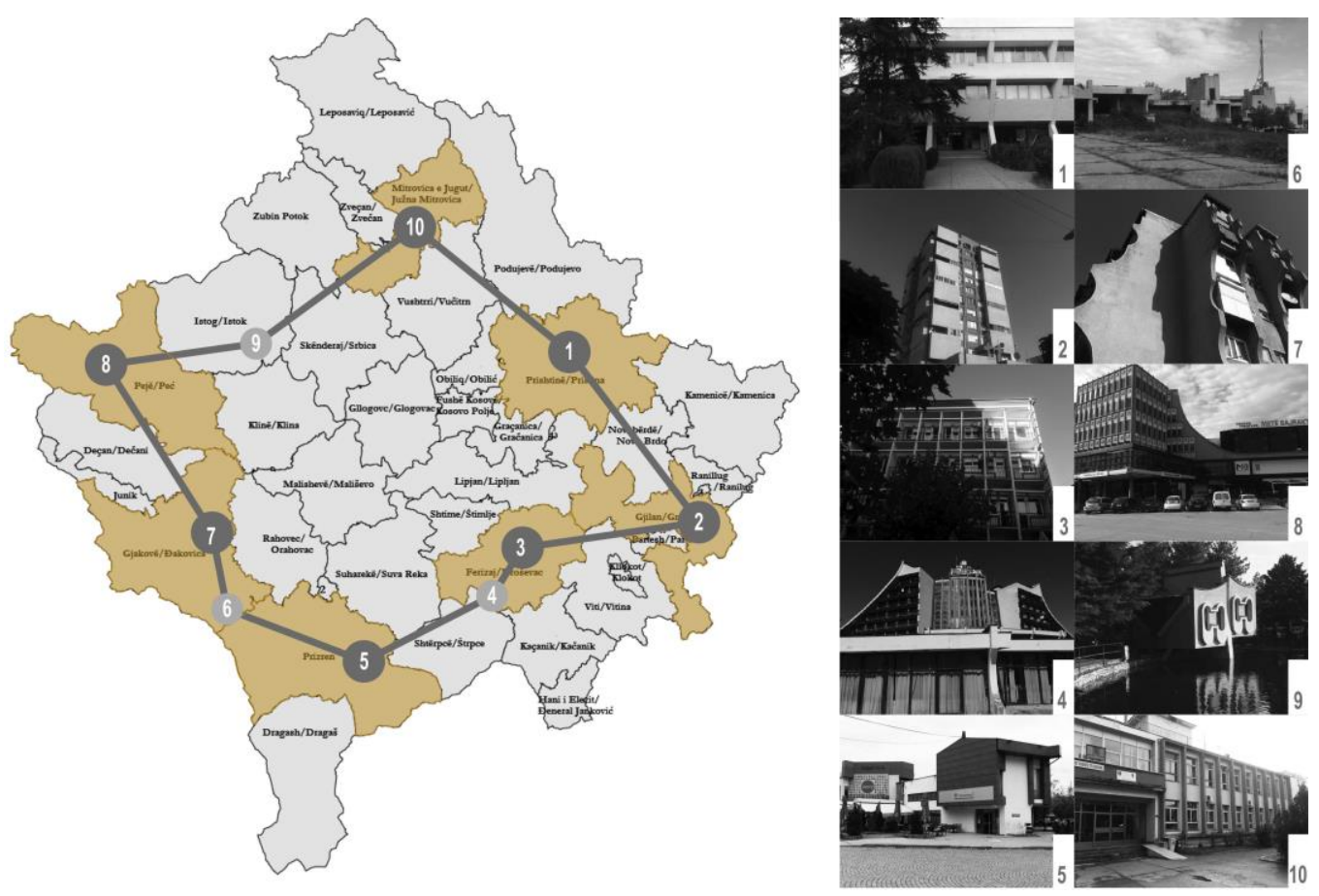

Figure 3: a. Overview of the development of modernist architecture of Kosovo in the main cities and touristic areas: 1. Institute of Albanology in Pristina, M.Pečič, 1975; 2. Residential Tower in Gjilan, M.Pečič, 1976; 3. Hotel Lybeteni in Ferizaj, D. Šugarčev, I.Šabič and M.Damjanovič, 1960; 4. Hotel "Narcis" in Brezovica, M.Durič, R.Stanojevič, 1978; 5. Shopping Mall in Prizren, Srbija Projekt, 1967; 6. Motel "Vëllazërimi" in Landovica, M.Pečič, 1973; 7. Apartment Buildings in Gjakova, M.Pečič,1976; 8. Shopping Mall in Peja, S.Zivkovič, $1978 ; 9$. Motel "Trofta" in Istog, Q.Beqiri, 1979; 10. Army House in Mitrovica, D. Hadzipešič, 1952. (C) Credits: authors

Kosovo modernist architecture began to be published in the main architectural magazines of the region ('Arhitektura Urbanizam - časopis za arhitekturu, urbanizam, primenjene umetnosti i dizajn'; 'Arhitektura - časopis saveza arhitekata hrvatske'). Some modernist buildings were included in foreign books on modern architecture as fine examples of 
modernism of the time [Kultermann, 1993]. In 1981, Kosovo modernist architecture of 1970s was presented among architecture of other republics in the Croatian magazine 'Arhitektura', speaking of similar architectural values and professional achievements during the 'golden ages' of architecture of Yugoslavia (Arhitektura 176+7/'81 and Arhitektura $178+9 / / 81$ ). This is one indication of the fact that gradually architecture fit the political and cultural agenda of the state, which was to raise Kosovo to the same level with the other republics of Yugoslavia.

Among the material production of the modernist period of Kosovo, we find architects from different nationalities (all from the region) that became actors of the modernist architecture of Kosovo. In the late '80ties, local architects were involved too in designing the most representative buildings.

Certain buildings designed and built by Kosovo and other Yugoslavian architects at the time, present some of the significant modernist architecture of Kosovo, listing here libraries: Kosovo National Library, A.Mutnjakovič, Pristina, 1973; cultural houses: Cultural House in Gjakova, S.Kepuska, Gjakova,1976; youth and sport centers: "Boro \& Ramizi", Ž.Jankovič, H.Muhasilovič, S. Ešpek, Pristina, 1973; hotels: Hotel Grand, B. Fehmiu, M. Jevremovič and D.Kovačevič, Pristina, 1978; Hotel "Narcis", M.Durič, R.Stanojevič, Brezovica, 1978; motels: Motel "Trofta", Q.Beqiri, Istog, 1979; Motel "Dardania", Q.Beqiri, Peja, 1977; Motel "Vëllazërimi", M.Pečič, Landovicë, 1973; media buildings: Media Building "Rilindja", G. Konstandinovski, Pristina, 1971; Radio Television of Kosovo, F. Rihtar, Pristina; research institutes and university buildings: Institute of Albanology, M.Pečič, Pristina, 1975; Technical Faculty, E.Ravnikar, Pristina, 1972; apartment buildings: Student Canteen, D.Radulovič, Pristina, 1974; Apartment Buildings in Gjakova, M.Pečič, Gjakova, 1976; residential towers: Residential Tower in Gjilan, M.Pečič, Gjilan, 1976; department stores: Department Store in Gjilan, M.Pečič, Gjilan, 1976; Department Store in Peja, S.Živkovič, Peja, 1978; office buildings: Kosovo Assembly, J.Neidhardt, Pristina, 1961; KEK building, Z.Zakič, Pristina, 1984; Post Office building, H.Muhasilovič, Pristina, 1983; Bank Office Building "Bankos", G.Kreitmayer, Gjakova, 1977; Post Office Building in Gjakova, G.Kreitmayer, Gjakova, 1977; railway stations: Fushë Kosova Railway Station, N. Dobrovič, Fushë Kosova, 1965; galleries: National Gallery of Kosovo, A.Beqiri, Pristina, 1989.

Among well known architects from the region, Kosovo architecture counts the contribution of Croatian architect Juraj Neidhardt ${ }^{16}$, Slovenian architect Edvard Ravnikar ${ }^{17}$; Macedonian architect Georgi Konstatinovski ${ }^{18}$, Bosnian architect Živorad Jankovič ${ }^{19}$ etc,

\footnotetext{
${ }^{16}$ Juraj Neidhardt (the author of Parliament Building in Pristina), has studied at the Academy of Fine Arts in Vienna (1924). He had working experience with Peter Behrens and Le Corbusier

${ }^{17}$ Edvard Ravnikar (the author of the Technical Faculty of Pristina), besides his studies at the Faculty of Architecture in Ljubljana, has a previously studied in Vienna (20ties) with working experience in the atelier of Le Corbusier

${ }^{18}$ Georgi Konstatinovski (the author of Rilindja Building in Pristina), besides his studies at the Technical Faculty of Skopje has further finished his Master studies at the School of Arts and Architecture of the Yale University in the USA (1965) with working experience at Yo Ming PEI Architects in New York

19 Živorad Jankovič, , besides his studies at the Faculty of Architecture in Belgrade, has completed his postgraduate course in Scandinavia (1960) and at the University of Michigan (1963).
} 
Out of a sudden, Kosovo became a place where different regional architecture school could be compered in a matter of their achievements and their 'products', since some of these buildings became good examples of modern architecture. National Library of Kosovo (Figure 4) was mentioned internationally (14th International Architecture Exhibition, Fundamentals) as one of the examples of regionalist architecture of the region.$^{20}$ Youth and Sports Center "Boro and Ramizi" (Figure 5) was elaborated as one of the three selected projects in the comparative article of modernist architecture of Yugoslavia "Tri Značajna Društvena Centra" [Mladenovič, 1982]. ${ }^{21}$ Motel "Trofta" was nominated and awarded with Borba Prize in 1981 (Figure 6), a competition organized for the best project realized in former Yugoslavia. Other significant achieving facts of Kosovo modernist buildings proof the architectural values of this period.
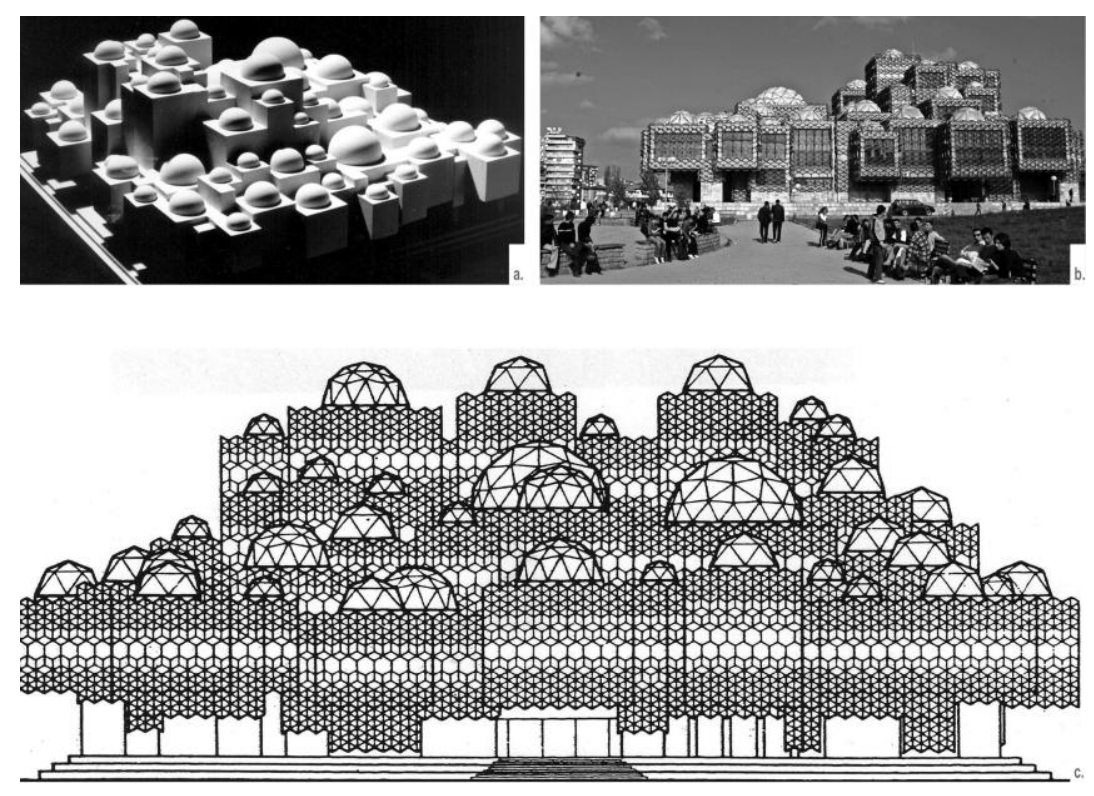

Figure 4: Kosovo National Library: a. paper model, 2. exterior view, 3. west facade. A.Mutnjakovič, Pristina, 1973. (c) Credits: Gjinolli, Ilir. and Kabashi. Lulzim. Kosovo Modern: An Architectural Primer. Prishtina: National Gallery of Kosovo, 2015

\footnotetext{
${ }^{20}$ Koolhaas, Rem. Fondazione La Biennale Di Venezia "Fundamentals Catalogue". Venice: Marsilio Editori, 2014.

${ }^{21}$ Mladenovič, D. (1082): Tri Značajna Društvena Centra, V: Arhitektura i Urbanizam, 88/89., Belgrade
} 


\section{JOSHA}

Journal of Science, Humanities and Arts

April 2021

Volume 8, Issue 2
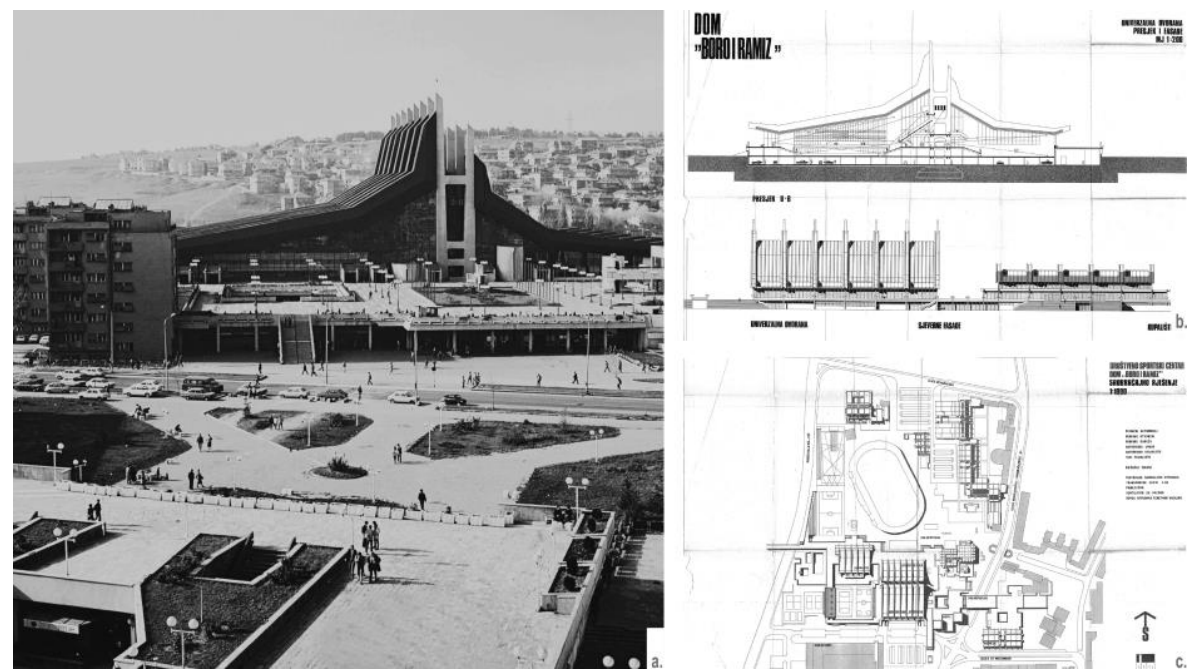

Figure 5. Youth and Sport Centers: "Boro \& Ramizi": a. exterior view, b. section and Facades, c. detailed plan. Ž.Jankovič, H.Muhasilovič, S. Ešpek, Pristina, 1973 @ Gjinolli, llir. and Kabashi. Lulzim. Kosovo Modern: An Architectural Primer. Prishtina: National Gallery of Kosovo, 2015

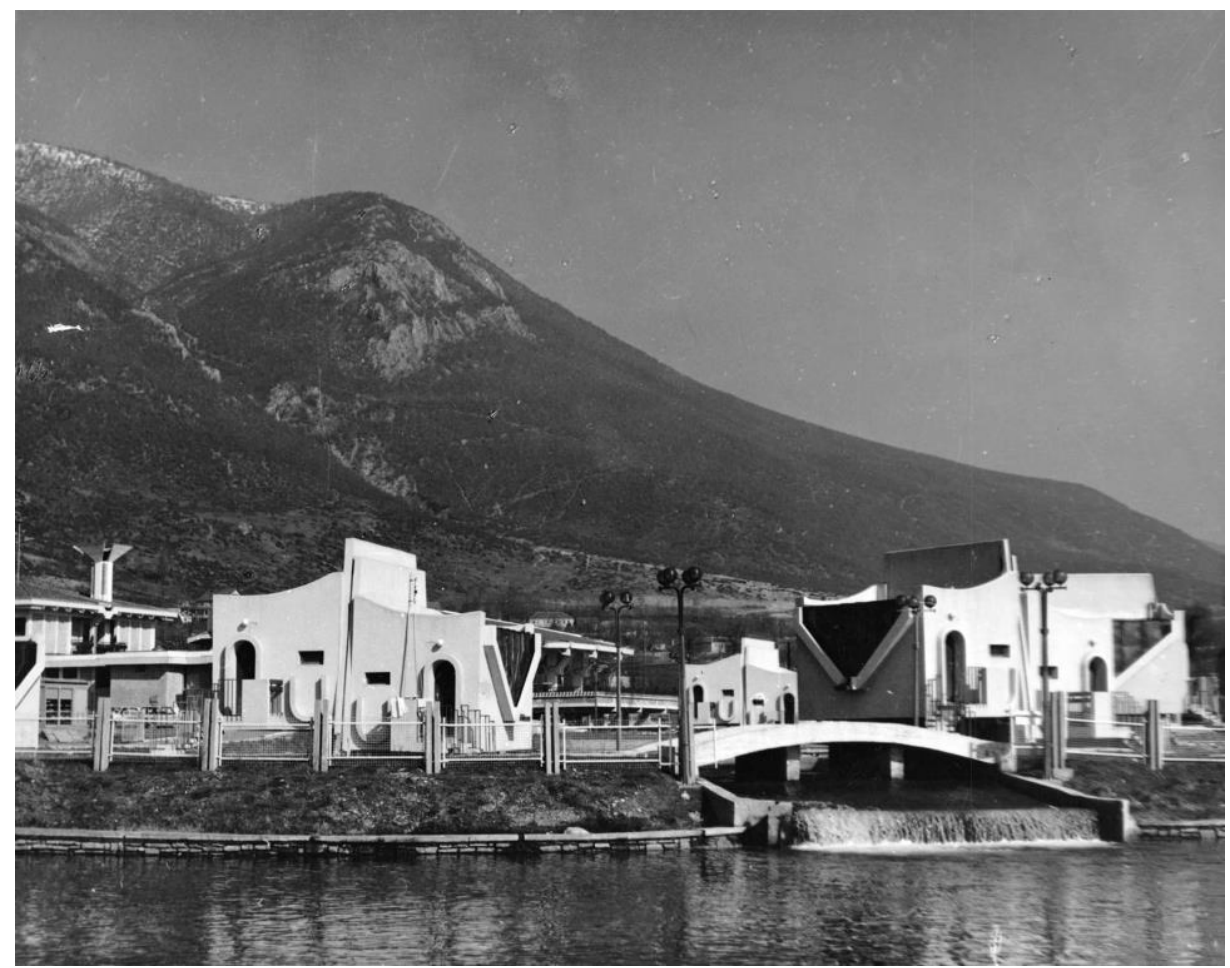

Figure 6. Motel "Trofta", Q.Beqiri, Istog, 1979. (C Credits: Gjinolli, llir. and Kabashi. Lulzim. Kosovo Modern: An Architectural Primer. Prishtina: National Gallery of Kosovo, 2015

\subsection{SECOND DESTRUCTION: VANISHING MODERNISM}




\section{JOSHA}

Journal of Science, Humanities and Arts

At the end of the 1980s, beginning of 1990s, intensity of the construction of modern architecture began to diminish. ${ }^{22}$ Significant political changes that took place in Yugoslavia in 1980s (after TITO passed away), affected also the socio - political and architectural situation in Kosovo. In 1991 Serbia took radical steps in excluding Albanians from the institutions, leading to '99s Kosovo War. ${ }^{23}$ With the independence of Republic of Kosovo, significant developments took place in the newly consolidated country. These developments influenced directly the inherited modernist architecture.

Kosovo, which after the end of the war was administrated by the UN Mission - UNMIK, witnessed rapid transitions in the administrative system. Kosovo cities were again attached with economic, political and social changes. What affected directly the modernist architectural and urban structures of Kosovo was the process of the privatization, as the most radical aspect of the transition from the socialist state system to the democratic and market system. ${ }^{24}$ During the privatization process, buyers of social properties were not limited for future interventions in respective facilities (Figure 7).
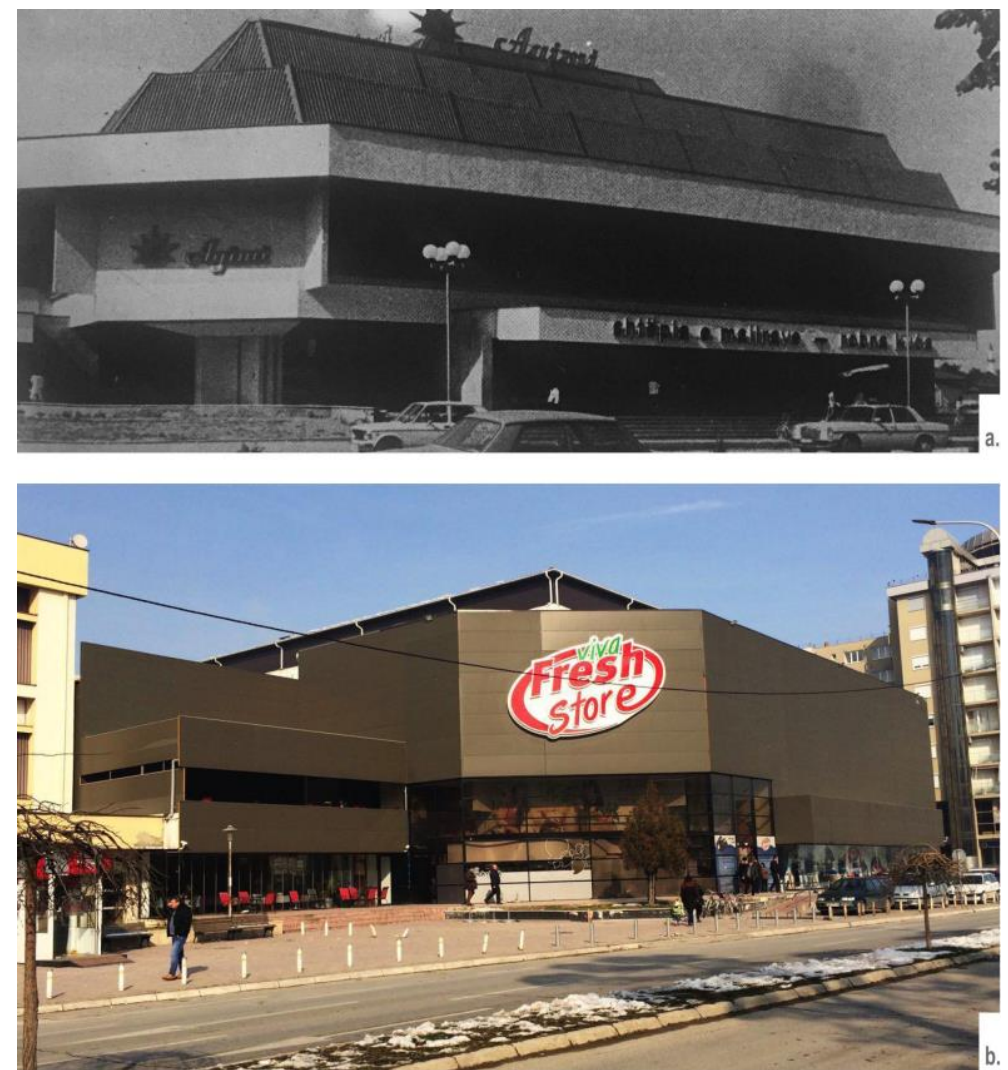

\footnotetext{
${ }^{22}$ Gjinolli, I., Kabashi, L. (2015): Kosovo Modern: An Architectural Primer. National Gallery of Kosovo, Prishtinë.

${ }^{23}{ }^{23}$ Ismajli, R., Kraja, M., (2011): Kosova, vështrim monografik. Akademia e Shkencave dhe e Artevetë Kosovës, Prishtinë.

${ }^{24}$ Gjinolli, I., (2015): Public Space in Kosovo - Transformations Through History, PhD diss. Graz University of Technology. Graz.
} 
Figure 7. Interventions in the initial state of the Shopping Mall "Agimi" in Gjakova after the privatisation process. T. Andjus, S.Kostič, 1976. (C) Credits: a. Dobroshi, Drita. Socijalistička Autonomna Pokrajina - KOSOVO DANAS. Belgrade: Izdavačka radna organizacija Svetozar Markovič, 1984, b. authors

Kosovo Cultural Institutions still do not legally protect modernist buildings (with only few exceptions), therefore they are not considered as national heritage values. Lately, after '99s war in Kosovo and Kosovo's independence many of the buildings that belong to modernist movement were reconstructed, going through major transformations. Concrete was replaced with new materials, questioning the identity of the building itself [Elezi, 2017]. ${ }^{25}$ Several were completely demolished. It is evident that Kosovo never absorbed modernity [Paçarizi, 2014]. ${ }^{26}$

At the end of this decade, we count decent degradation of the modernist buildings. The changes that inherited modernist architecture is facing nowadays could be classified as following: (1). The already demolished buildings, mostly from the industrial zones; (2). Renovated buildings with major changes in volumes and materials: Media Building "Rilindja" in Pristina, Hotel "Bozhuri" in Pristina, Grand Hotel in Prishtina, Technical Faculty in Pristina, Shopping Mall "Agimi" in Gjakova, Furniture Shopping Mall in Prizren, etc., (Figure 9, 10 \& 11); (3). Buildings that have left abandoned: Hotel "Narcis" in Brezovica, Motel "Vëllazërimi" in Landovica etc. Other disquieting factor of the degradation of modernist buildings in Kosovo are: various annexes added to existing facilities which do not relate to the character of the original state of the building and poor maintenance that applies to the majority of modernist buildings in Kosovo.

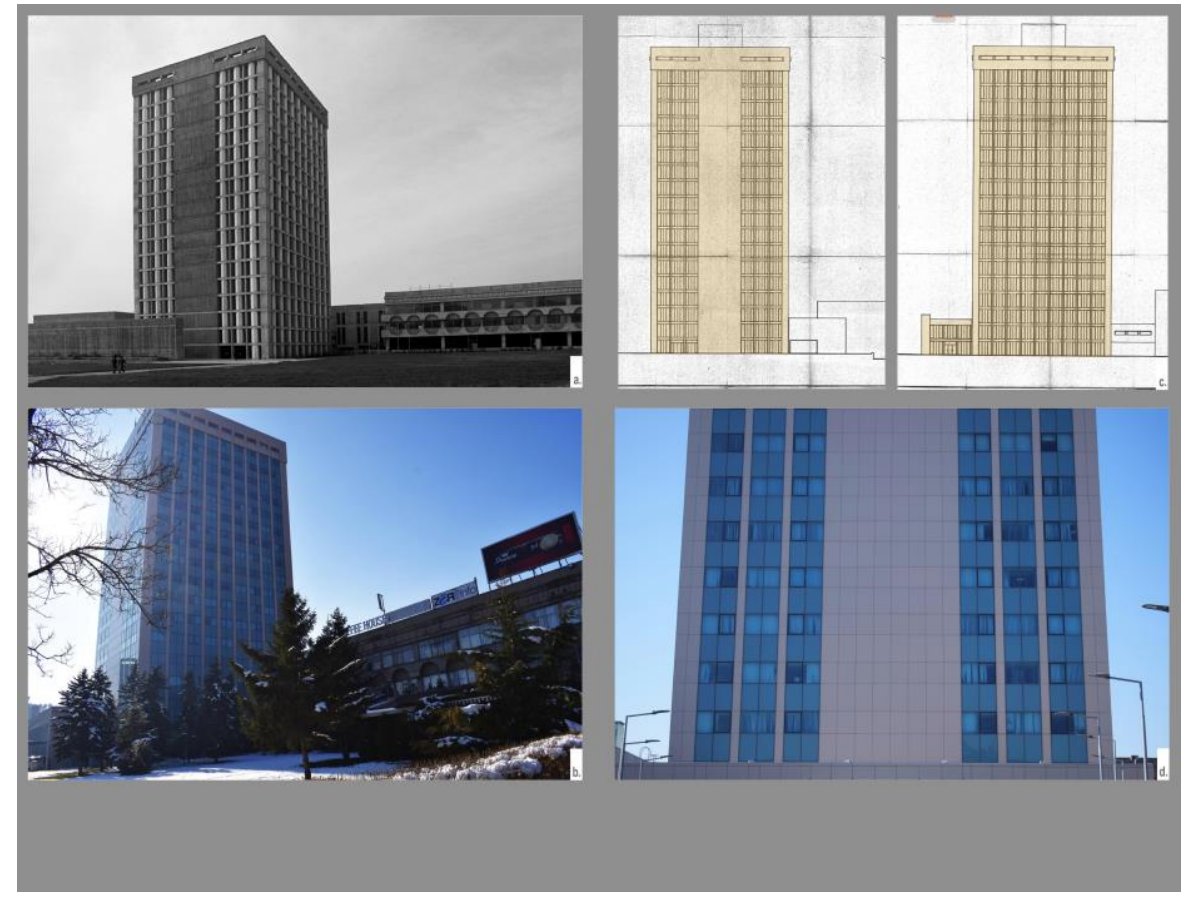

\footnotetext{
${ }^{25}$ Elezi, Kujtim. "Humbja e identitetit të kryeqytetit." Koha Ditore, March 18, 2017. 27

${ }^{26}$ Paçarizi, Gëzim. Biennale Book, Prishtina: Kushtrimbalaj B.I., 2015.
} 


\section{JOSHA}

Journal of Science, Humanities and Arts

Figure 8. Media Building "Rilindja", G. Konstandinovski, Pristina, 1971; Comprehension of the initial state (a) with the interventions after the latest renovation. Parts of the facades that have been coated with contemporary materials (c). Detail of the current state of the façade (d). @ Credits: a, c: Gjinolli, Ilir. and Kabashi. Lulzim. Kosovo Modern: An Architectural Primer. Prishtina: National Gallery of Kosovo, 2015; b,d: authors

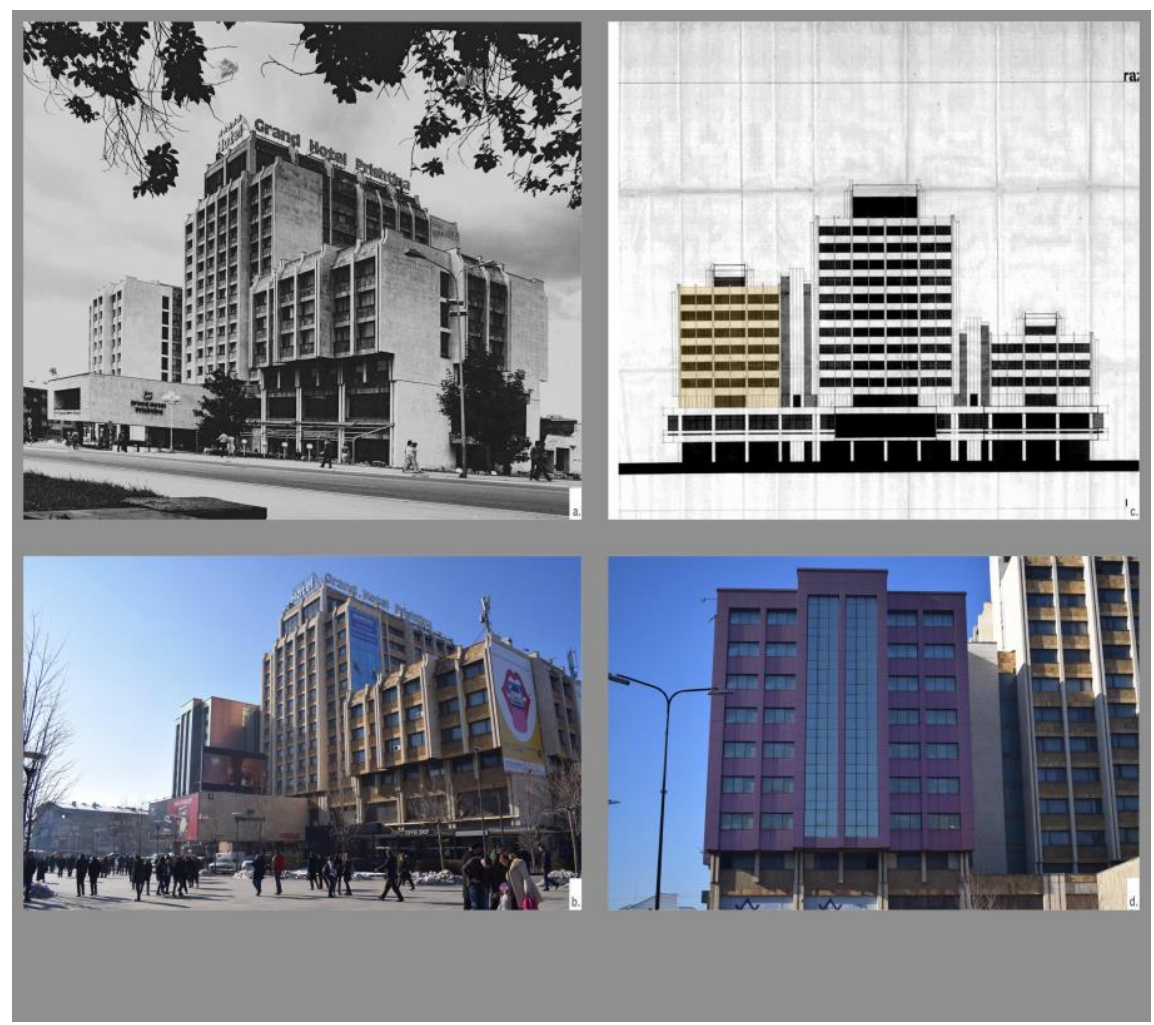

Figure 9. Hotel Grand, B. Fehmiu, M. Jevremovič and D.Kovačevič, Pristina, 1978; Comprehension of the initial state (a) with the interventions after the latest renovation. Part of the facade that has been coated with contemporary materials (c). Detail of the current state of the façade (d). @ Credits: a, c: Gjinolli, llir. and Kabashi. Lulzim. Kosovo Modern: An Architectural Primer. Prishtina: National Gallery of Kosovo, 2015; b,d: authors 
Journal of Science, Humanities and Arts

April 2021

Volume 8, Issue 2

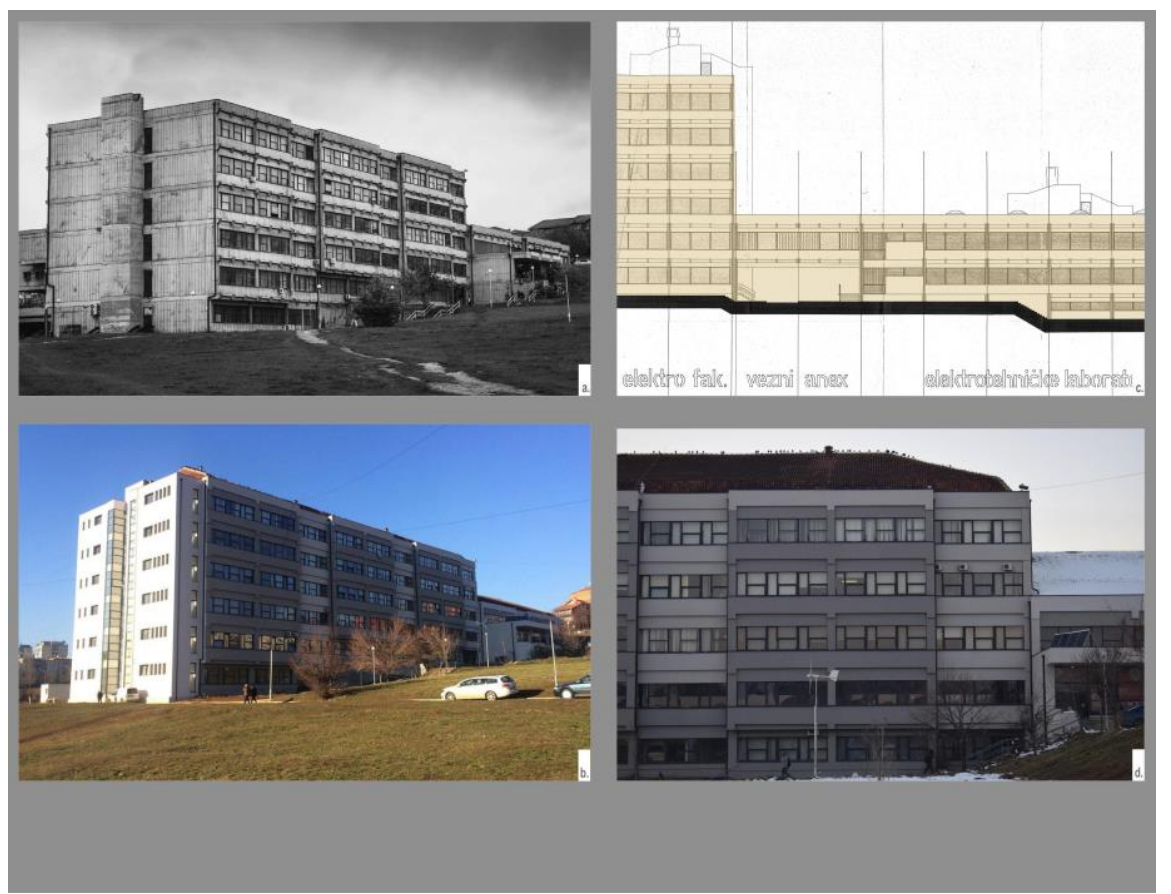

Figure 10. Technical Faculty, E.Ravnikar, Pristina, 1972; Comprehension of the initial state (a) with the interventions after the latest renovation. Part of the facades that have been coated with external thermal isolation and final façade materials (c). Detail of the current state of the façade (d). (C) Credits: a, c:

\section{KOSOVO MODERNISM AND THE PROCESS OF METAMORPHOSIS}

The political and social context of the construction of Kosovo modernism and the current state of modernist iconic buildings in Kosovo, show that Kosovo modernism could be considered as a process itself (Figure 11). The life of modernist buildings in Kosovo could be considered a process of metamorphosis. This process counts several stages of deconstruction and construction. Initially, the arrival of modernity determines the deconstruction of the traditional architecture that had strong identity connotation. In order to bring modernism, Kosovo architecture has undertaken a dominant process of construction. Certain decades of designing and implementing modernism brought in line several architecture and urban planning projects, but little valued and appreciated in the public context. This leaded to the current state, the second deconstruction faze, that of the fading of Kosovo Modernist Architecture.

The deconstruction of Kosovo modernism is continuously vanishing an important period of Kosovo's architecture. Even though a considerable number of modernist building of Kosovo present good examples of modernist architecture within Yugoslavia, inside national borders they are not valued, and therefore not even protected. On-going interventions in the modernist structures have endangered some of the iconic modernist buildings of the time. 


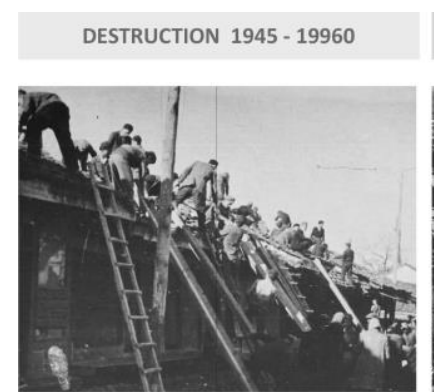

CONSTRUCTION $1960-1990$

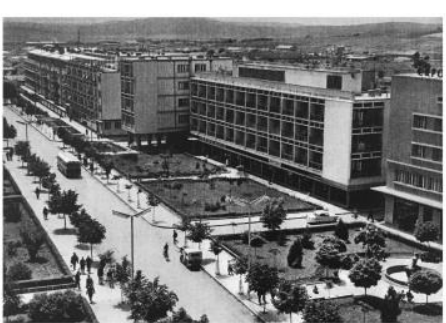

DESTRUCTION 2000 - (ongoing)

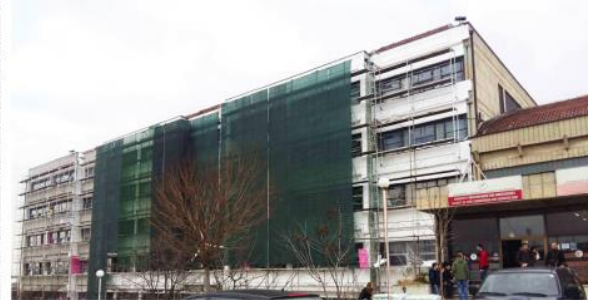

Figure 11. The process of the evolution of Kosovo Modernism a. destruction of the Old Market (Çarshia) in

Pristina; b. construction of the city center of Pristina; c. renovation of the Technical Faculty in Pristina, designed by Edvard Ravnikar. @ Credits: a. Cultural Heritage Without Borders. Heritage of Pristina - Remained Heritage of Pristina. Pristina: Prograf, 2008; b. Časopisa "Revija". Gradovi Jugoslavije, Grafiçki Zavod Hrvatske, 1965, c. authors

\section{CONCLUSIONS}

Kosovo modernism presents a reach period of Kosovo's architecture. Even though many of the buildings of this period present the most remarkable and iconic buildings of all times, it is not nationally valued as a 'decent' architectural period. Many reasons have affected this judgment, and the results are already seen, among endangered buildings of this period.

It is evident that modernism in Kosovo was imposed, and therefore was seen as something not connected with the national values and national (professional) actors. Because of this fact, it remained un-appreciated and un-promoted, keeping it un-valorised and undocumented. Without having considered the values of this architecture period yet, many of modernist buildings were demolished or faced major interventions that vanished the initial state.

Still, Kosovo modernism remains not researched and analysed for the values that presents. Many architectural solutions of the time could be considered as national tools for brining Kosovo in the same level of other republics of Yugoslavia, politically, socially and most importantly, professionally.

This paper opens the discussion on the importance of brining light to the journey of Kosovo modernism, its construction and de-construction phases and the reasons after the neglected appreciation of its values. It tries to brings the attention in the initial and current state of some most valuable modernist buildings of the time in order to show the importance these architecture examples and the major changes that they've witnessed in the last decade. And by so, it aims to show the hidden values of Kosovo modernist architecture and the urge for its valuation, documentation and preservation. 


\section{REFERENCES}

iscepi]lashari-Kajtazi, Teuta. "BEHIND THE NATIONAL IDENTITY; Political and Social Activity through Architecture - Liberal Socialism in Kosovo", PhD diss. Wien: TU Wien, 2016

Elezi, Kujtim. "Humbja e identitetit të kryeqytetit." Koha Ditore, March 18, 2017

EU/CoE Support of Promotion of Cultural Diversity (PCDK). Conservation Bases for the Historic Centre of Pristina. Pristina, 2012

Fehmiu, Bashkim. "Prizren - Remek Delo Nepoznatih Majstora" Arhitektura i Urbanizam, 1964-95. Belgrade: 1971

Gjinolli, Ilir. and Kabashi. Lulzim: Kosovo Modern: An Architectural Prim- er. Prishtina: National Gallery of Kosovo, 2015

Gjinolli, llir. "Public Space in Kosovo - Transformations Through History", PhD diss. Graz: Graz University of Technology, 2015

Hoxha, Eliza. Qyteti dhe dashuria. Prishtinë: Qendra për hulumtime humanistike, 2013

Ismajli, Rexhep. and Kraja, Mehmet. "Kosova, vështrim monografik". Prishtinë: Akademia e Shkencave dhe e Arteve të Kosovës, 2011

Kultermann, Udo. Architecture in the 20th Century. New York: Van Nos- trand Reinhold, 1993

Koolhaas, Rem. Fondazione La Biennale Di Venezia "Fundamentals Catalogue". Venice: Marsilio Editori, 2014

Limani, Mrika. "Kosova in Yugoslavia - Against colonial status," in Yugosla- via from a Historical Perspective, ed. by Perovič, Latinka. Roksandič, Drago. Velikonja, Mitja. Hoepken, Wolfgang. and Bieber, Florian. Belgrade: Helsinki Committee for Human Rights in Serbia, 2017

Mladenovič, Dimitrije. "Tri Značajna Društvena Centra." Arhitektura i Urbanizam, 88/89. Belgrade: 1982

Mrduljoš, Maroje., Kulič, Vladimir and McMaster, Graham. Unfinished modernisation: between utopia and pragmatism (architecture and urban planning in the former Jugoslavia and the successor states). Zagreb: UHA/ CCA, 2012

Mutnjakovič, Andrija. "Dileme kosovske arhitekture" Arhitektura - časopis saveza arhitekata hrvatske, 178+9/'81. Zagreb: 1981 
Štraus, Ivan. Arhitektura Jugoslavije : 1945-1990. Sarajevo: Svjetlost, 1991

Vladimir, Kulič. Maroje, Mrduljaš. and Wolfgang, Thaler. Modernism In-Between, The Mediatory Architecture of Socialist Yugoslavia. Berlin: ISBN 978-86859-147-7

Xërxa Beqiri, Flaka. "The dominant example of Kosovo's Modern Architecture - Presentation of the National Library of Kosovo, an icon of the Modern Architecture Heritage of Kosovo". Piranesi, No.40, Vol. 26. Ljubljana: 2018

Xërxa Beqiri, Flaka. "The undiscovered modern architecture of Kosovo - Overview of modernist architecture in Kosovo, a fading architectural heritage". Piranesi, No.40, Vol. 26. Ljubljana: 2018

Xërxa Beqiri, Flaka. and Navakazi, Vlora. "The life of Kosovo Modernism". 15th International DOCOMOMO Conference "Metamorphosis - The continuity of change", August 28, 2017. Ljubljana: 2017 